\title{
School Plant and Success of Entrepreneurial Subjects in Public Secondary Schools in Afikpo Education Zone of Ebonyi State
}

\author{
Dr. Uwaoma Akwu Ude \\ Dept. Of Social Studies \\ Ebonyi State College Of Education \\ Ikwo \\ Dr. Uma Sunnny Okechukwu \\ Education Authority \\ Ohaofia LGA Abia State \\ Dr. Nwose Livinus \\ Dept. Of Social Studies \\ Ebonyi State College Of Education \\ Ikwo \\ Contact: $08067241221 \& 07089887913$ \\ Email:Uwaku2000@gmail.com \\ DOI: $10.31364 /$ SCIRJ/v7.i7.2019.P0719673 \\ http://dx.doi.org/10.31364/SCIRJ/v7.i7.2019.P0719673
}

\begin{abstract}
The research study investigated the availability of school plants and success of entrepreneurial subjects in secondary schools in Afikpo Educational Zone of Ebonyi State. The design of the study was a descriptive survey which had a population of Ninety five (95) principals and the sample wad s purposive sample ad the entire Ninety five (95) was converted to be sample. The instrument used for the study ws a 10 item structured questionnaire titled school plant and the success of the entrepreneurial subject's questionnaire (SPESQ). Two (2) research questions and two (2) hypotheses were formulated to guide the study. The hypotheses were tested at 0.05 level of significance and mean was used in answering the research questions while Z-test was used in testing the hypotheses. The finding reveled that only few schools had listed school plants and the available ones were not used because of lack of subject teachers in the subjects it was recommended that Government provide enough equipment and personnel ready before introducing any innovating curriculum in her schools.
\end{abstract}

KEYWORDS: School Plant, Entrepreneurial Subjects, Secondary School, Principal, Trade Subjects.

\section{Background to the Study}

Schools are established to institute and facilitate desirable changes in the behavior of students under the guidance of the teacher. For changes of behavior to occur teachers are expected to expose students to attain instructional goes and under some conducive environmental conditions, (Osunde, 2007). 
Okeke (2004) maintained that formal education takes place in a circumcised environment with facilities, personnel and curricular packages for achievement of pre-determined societal goals. He further maintained that School is a social system characterized by formal structures and fabric with different people playing different roles.

In Nigeria, school as an agent of modernization has witnessed a number of reforms including the introduction of the 6-3-3-4 education system. The Universal Basic Education (UBE) as well as new curricular education system include modern mathematics, social studies, civic education and gamut of 34 new entrepreneurial subjects.

Most of these new reforms and curricular packages have not stood firm in the school system because if poor planning and nonavailability of appropriate facilities for their implementation. The problem of the present day Basic Education as in the case of pervious Universal Primary Education is the dearth of implementation, facilities in the right quantity and quality (Ezeife, 1998).

The school plant is the fundamental infrastructure required for the running of a school. Enaohwo and Eferakeya (1990) defined school plant as the entire scope of infrastructural facilities provided in the school for the purpose of educating the child. For Maduagwu and Nwogu (2006) school plant include school building grounds, equipments, lawns and paths, furniture, fields, laboratory, libraries, tools and machines, chalk boards etc where those facilities are not available in their right form, quantity and quality. The school curriculum suffers the loss of success within its implementation period.

Nigeria since independence has lagged far behind in the word technological development it has made several unsuccessful attempt to queue up on the live of technologically developing nations like India, Korea and lately China. For instance in the early days of independence, she established technical schools and colleges, in the 1990s in each of the 36 states of Nigeria and the federal capital territory. In late 1990s and early 2000 she established technical colleges of Education, polytechnics and monothenics as well as universities of technology like the Federal University of Technology Owerri among others, as if these were not enough. The Nigeria Education policy planners have gone down to the secondary schools level to introduce a whooping number of 34 trade or entrepreneurial subjects.

What borders this researcher is the state of the plants in the schools for the implementation of the trade subjects. One is not sure of which plants are readily available in the schools, their usability, conditions, which once have been provided by government since the introduction of the trade and entrepreneurial subjects an which one needs to be provided to meet the tutorial demands of the secondary schools and to help achieve the objectives of entrepreneurial education in Afikpo Education Zone of Ebonyi State.

\section{Statement of the Problem}

Nigeria education policy planner have taken a bold step to introduce trade and entrepreneurial subjects in the secondary schools to make Nigeria youths self employable on graduation from the secondary schools laudable those attempts and efforts are one still remains in doubt as the readiness of the government to truly implement these trade curricular. The school plants required for effective implementation of those curricular one either not in good state of use or not available at all. In Ebonyi State most schools do not have introductory workshops or any workshop at all. Some schools do not have sufficient ground space to set up these workshops.

Each of these trade and entrepreneurial subjects requires its own peculiar equipment for successful teaching. A cursory visit and a look at the secondary schools will slow that absolutely nothing in the form of equipment is on ground for teaching those subjects. 
The schools that has introductory technology equipment given to them in the 1980s, have been vandalized and obsolete in use. Infact since the introduction of the trade and entrepreneurial subjects in the national policy of Education (2004 edition) and it's been made compulsory by the 2013 edition, no provision in form of school plants have been made available to the schools. What beats the imagination of the researcher is can the available school plants suffice for the implementation of the trade and entrepreneurial subjects in Afikpo Education Zone of Ebonyi State.

\section{Purpose of the Study}

The primary purpose of this study was to investigate the availability of schools plants for the successful implementation of trade and entrepreneurial subjects in secondary schools in Afikpo Education Zone of Ebonyi State.

Specifically the study tried to:

1. Find out which school plants that are available for the successful teaching and learning of trade and entrepreneurial subjects.

2. Find out the available school plants that are actually used for teaching and learning of entrepreneurial subjects.

\section{Justification for the Study}

The findings of this study will be significant to the stakeholders in the education system is Ebonyi State and Nigeria at large. There are the government, the teachers, the learners and the parents. The government will benefit because she will know the available school plants necessary for the teaching of entrepreneurial subjects and also the obsolete and new ones.

The learners will also benefit because the final report will motivate government to provide what will be used in the teaching of trade subjects such as infrastructural facilities and other resources for the schools to teach the trade subjects.

Parents will benefit from the report of this study based the fat that their children will start getting maximum benefit they expect from this school in relation to teaching of trade subjects, parent will be happy as their children will become self employable after secondary education.

\section{Research Questions}

The following research questions were formulated to guide the study.

1. How has the available school plant been successful for teaching of entrepreneurial subjects?

2. What are the effects of using the available schools plants in the successful teaching and learning entrepreneurial subjects?

\section{Research Hypotheses}

$\mathbf{H O}_{1}$ : There is no significant difference between the mean rating score of rural and urban secondary schools principals on the school plants available for teaching of trade subjects @ 0.05 level of significant.

$\mathbf{H O}_{2}$ : There is no significant different between the mean rating scores of rural and urban secondary school plants that are actually used for teaching of entrepreneurial subjects $\mathrm{P}<0.05$. 


\section{Area of the Study}

The study was carried out is Afikpo Educational Zone of Ebonyi State. The area has schools at are distributed in both rural and urban areas. The inhabitants are mixture of civil servants and farmer with few artisans.

\section{Population for the Study}

The population for this study consist of all the principal in secondary schools in Afikpo Education Zone. The population was made up of the Ninety Five (95) principal in the secondary schools in the zone.

\section{Sample and Sampling Technique}

The purposive sampling technique was adopted and the entire population of Ninety five (95) principals was used as the sample for the study.

\section{Instrument for Data Collection}

The instrument used for data collection was a 10 item structure questionnaire titled "School Plant and Entrepreneurial Subjects Questionnaire (SPESQ). The instrument was divided into two parts: A and B.

Part A is the personal date of the respondents while part B is score items. The research use the licket style of strongly agree (SA) agree (A) strongly disagree (SD) disagree (D) weighted 4,3,2,1 respectively.

\section{Reliability of the Instrument}

The researcher produced (30) copies of the questionnaire were distributed to principal outside the researcher area of study and result was collected and re-administered after two weeks and collected and using Pearson moment correlation co-efficient statistic for analysis the result showed a reliability of 0.83 which was accepted and used.

\section{Method of Data Collection}

The data for the study was collection by personal hard deliver of the instrument to the respondents with the aid of research assistant drained for this study.

\section{Method of Data Analysis}

The data collected were analyzed with mean serves for the research questions and t-test was used for testing the hypothesis.

\section{Research Question One:}

To what extent are the available school plants used for the teaching of entrepreneurial subjects.

Table (1): Result of Analysis

\begin{tabular}{|c|l|c|l|l|l|l|l|}
\hline S/N & Extent of use of school plants & SA & A & SD & D & Total & X \\
\hline 1. & $\begin{array}{l}\text { The available school plants are effectively used } \\
\text { for teaching of entrepreneurial subjects. }\end{array}$ & - & 46 & 30 & - & 76 \\
\hline 2. & $\begin{array}{l}\text { Only few of the school plants and very well for } \\
\text { teaching/ learning of entrepreneurial subjects. }\end{array}$ & - & - & 10 & 90 & 11 & 0.80 \\
\hline
\end{tabular}




\begin{tabular}{|c|l|c|c|l|l|l|l|l|}
\hline 3. & $\begin{array}{l}\text { None of the available school plant is good for } \\
\text { proper teaching and learning and trade subjects. }\end{array}$ & - & - & 90 & 50 & 140 & 1.47 & $\mathrm{R}$ \\
\hline 4. & $\begin{array}{l}\text { I have not tried to use any of the school plants to } \\
\text { the trade subjects }\end{array}$ & - & - & 10 & 90 & 100 & 1.05 & $\mathrm{R}$ \\
\hline 5. & $\begin{array}{l}\text { Some of available school plants are managed in } \\
\text { teaching of trade subjects. }\end{array}$ & - & - & 6 & 92 & 98 & 1.03 & $\mathrm{R}$ \\
\hline
\end{tabular}

Note: $\mathrm{R}=$ Rejected, $\mathrm{A}=$ Accepted

Result of data analysis presented in table one (1) shows that the respondents agreed that only little available school plants are used in teaching the trade subjects. This was observed from the cluster mean which has a value of 0.80 and was rejected, only few available school plants are effectively utilized has mean of 1.05 and was rejected. None of the available school plants are very well utilized has 1.47 and was rejected. Have not tried some of the available plants had a mean of 1.05 and was rejected merely managing some of the available plants had 1.05 mean and was rejected.

\section{Research Question Two:}

What are the effects of using the teaching learning of entrepreneurial subjects.

Table (2): Data Analysis on the extent of the teaching and learning entrepreneurial subjects.

\begin{tabular}{|c|l|l|l|l|l|l|l|l|}
\hline S/N & Extent of utilization of plant & SA & A & SD & D & Total & X & R/A \\
\hline 6. & $\begin{array}{l}\text { The available school plants do not make } \\
\text { teaching of the subject teaching. }\end{array}$ & 8 & 9 & 2 & 86 & 105 & 1.67 & $\mathrm{R}$ \\
\hline 7. & They provide enough teaching experience & & & 10 & 90 & 100 & 1.05 & $\mathrm{R}$ \\
\hline 8. & They are enough to go round the students & 4 & 15 & - & 90 & 109 & 1.15 & $\mathrm{R}$ \\
\hline 9. & $\begin{array}{l}\text { They make our teaching and learning to be } \\
\text { modern }\end{array}$ & 3 & 10 & 89 & 102 & 1.07 & $\mathrm{R}$ \\
\hline 10. & $\begin{array}{l}\text { They do not gets spoilt and suddenly stop our } \\
\text { studies. }\end{array}$ & & & 8 & 91 & 99 & 1.04 & $\mathrm{R}$ \\
\hline & Cluster Mean & $\mathbf{1 . 2 0}$ & & & & & & \\
\hline
\end{tabular}

The Result of data analysis shown in table two states that the respondents agreed that the use of the available school plants for teaching entrepreneurial subjects has little effect on teaching and learning of trade subjects. This was observed from the cluster mean of 1.20. From the table the available school plants making teaching of trade subjects teaching has mean of 1.67 and was rejected not providing enough learning experience, has mean of 1.05 and was rejected. Not enough to go round the students has man of 1.15 and was rejected, not making teaching and learning modern has mean of 1.07 and was rejected. Getting spoilt of lesson had a mean of 1.04 and was rejected.

\section{Hypothesis One:}

To what extent are the available school plants used for the teaching of entrepreneurial subjects.

Table (3): Result of Z-test on the available school plants for teaching trade subjects

\begin{tabular}{|l|l|l|l|l|l|l|l|l|l|}
\hline SOURCE & F & FA & FNG & DF & $\begin{array}{l}\text { X2 } \\
\text { Cal }\end{array}$ & $\mathbf{Z}$ & $\begin{array}{l}\mathbf{Z} \\
\text { Crit }\end{array}$ & P & Decision \\
\hline Rural & 35 & 10 & 25 & 1 & 1.24 & 1.11 & 1.65 & $<0.05$ & Do not reject HO \\
\hline Urban & 60 & 10 & 50 & & & & & & \\
\hline
\end{tabular}


Result of hypothesis test presented in table (3) shows that there is no significant difference between the mean rating scores of rural and urban schools principals on the school plant available for teaching entrepreneurial subjects. This was observed from the calculated of 1.24 which is less than the critical of 1.65 from the table there are 35 rural principal with 10 of them available and 25 of them saying the plants are not available.

There are 60n urban principals with 10 of them saying that the plants are available and 50 saying they are not available, the degree of freedom (DF) of X2 is 1.24 with a $\mathrm{Z}$ cal. equipment of 1.11 the probability level was 0.08 the critical $\mathrm{X}^{2}$ was 3.84 with a $\mathrm{Z}$ equivalent of 1.68 at both $\mathrm{X}^{2}$ and $\mathrm{Z}$ the null hypothesis was rejected.

\section{Hypothesis Two:}

There is no significant difference between the mean rating score of rural and urban secondary school principal on available school plants actually used for teaching the trade subjects.

Table (4): Result of Z-test on the available school plants for teaching the trade subjects

\begin{tabular}{|l|l|l|l|l|l|l|l|l|l|l|}
\hline SOURCE & F & FA & FNG & DF & $\mathbf{P}$ & $\begin{array}{l}\mathbf{X}^{2} \\
\text { Cal }\end{array}$ & $\begin{array}{l}\mathbf{X} \\
\text { Crit }\end{array}$ & $\begin{array}{l}\mathbf{Z} \\
\text { Cal }\end{array}$ & $\begin{array}{l}\mathbf{Z} \\
\text { Crit }\end{array}$ & Decision \\
\hline Rural & 35 & 14 & 14 & & & & & & & Do not reject HO \\
\hline Urban & 60 & 6 & 6 & 1 & $<0.05$ & 0.02 & 3.84 & 1.13 & 1.65 & \\
\hline
\end{tabular}

Result of hypothesis test presented in table (4) shows that there is no significant difference between the mean rating in the rural and urban entrepreneurial subjects. This was observed from the calculated 2 values of 0.13 which is less than the critical of 1.65 from the table the number of rural principals was 35 and 4 saying that the plants are not used. The degree of freedom was 1 while the probability value was 0.05 . The calculated $\mathrm{X}^{2}$ was 0.02 with calculated 2 equivalent of 0.13 , the critical $\mathrm{X}^{2}$ value was 3.8 with critical 2 equivalent of 1.65 . Since the critical value of both the $X^{2}$ and 2 were both less than their critical values the null hypotheses was nit rejected.

\section{Conclusion}

Based on this study, these are a number of infrastructures that were in our schools at the inception of these schools. The school plants as they were called were put in place bearing in mind the nature of the curriculum that ws in place as they were introduced that suited the arts, social sciences, humanities and the pure sciences.

It was only at the introduction of introductory technology subjects in 1970s, that the need for technical equipment became important and the once bought once kept without adequate security and enough man power to take care of this equipments and they were quickly vandalized as soon as they were installed, this also affected the Grammar subject as most laboratories equipment were equally vandalized and this has hindered the development of trade subjects in secondary schools in Nigeria.

It is only the aspect of the Agricultural Sciences, Accountancy, book keeping and computer sciences that some school deem they do as trade subjects. A thorough examination of how there subjects are taught do not show a notable departure from the way there were been taught before. It is clear from this research that they are dearth if equipment and personnel for the teaching of these subjects as the principals have complained. 


\section{Recommendations}

Based on the findings of these study the following recommendation are made:

(1) Three result from the findings showed that insecurity is one of the major problem as school plants are been vandalized, therefore principal should employ enough security to guide school plants with the consent of the Government.

(2) Government should found schools and provide enough school plants and subject teachers to teach trade subjects in secondary schools.

\section{References}

Enahomo-J.O. \& Eferkaya, O.A (1989) Educational Administration Ibadan; paperback publishers.

Ezeife, A.N. (1998) Barrier factors in effective curriculum development, implementation and evaluation in Nigeria in B.G. Nwigy (Eds) curriculum development and implementation and evaluation: A Book of Reading, APONENT, publication.

Federal Republic of Nigeria (2004) National Policy on Education Lagos; NERDC.

Okeke B.S. (2004) Teaching in Nigeria; the Bureaucracy professionalism, Enugu: Mercury International Publishers.

Osunde, A.U (2007) the Relevance of Education in Teaching and Learning in the school system principals year book. 